Acta Technologica Agriculturae 1

Nitra, Slovaca Universitas Agriculturae Nitriae, 2018, pp. 14-17

\title{
ANALYSIS OF SELECTED PHOTOVOLTAIC PANELS OPERATING PARAMETERS AS A FUNCTION OF PARTIAL SHADING AND INTENSITY OF REFLECTED RADIATION
}

\author{
Matúš BILČÍK*, Monika BOŽIKOVÁ, Ana PETROVIĆ, Martin MALÍNEK, Vladimír CVIKLOVIČ, \\ Martin OLEJÁR, Veronika ARDONOVÁ
}

Slovak University of Agriculture in Nitra, Slovak Republic

\begin{abstract}
Due to expansion of utilisation of photovoltaics in ordinary households, the question arises how this phenomenon affects the electric power of photovoltaic modules. The article deals with the electric power analysis of photovoltaic modules as a function of two very important factors. The first examined factor was partial shading, and the second factor was the intensity of reflected radiation. In order to determine the dependence of module power on the aforementioned parameters, a measurement system under laboratory conditions has been prepared. For identification of the reflected radiation effect on the power of the photovoltaic module, a series of measurements was performed on 7 different surfaces with the same radiation source. It is evident from obtained experimental result that the ratio of reflected irradiation on the solar module power is $1.29 \%$. By simulation of partial shading of photovoltaic module, the decrease of $86.15 \%$ in its output power was identified.
\end{abstract}

Keywords: PV module; power; solar irradiation; cells obscuration

Photovoltaics is a significantly widespread source of renewable energy. It can be used in two forms: either fixed or portable. The efficiency of photovoltaic (PV) panels has considerably increased over the past decade. Nowadays, the PV also gets into ordinary households thanks to subsidies for the use of renewable energy sources (Libra et al., 2017; Libra et al., 2016; Olšan et al., 2016; Poulek et al., 2016). Photovoltaics is a set of technologies using semiconductors to convert sunlight (photons) into electricity. The process of energy conversion is direct; no emissions of greenhouse gases or particulates are released. The process of light conversion into electricity (photovoltaic effect) was discovered by Alexander Bequerel in 1839. This effect is used in PV modules (McEvoy et al., 2011).

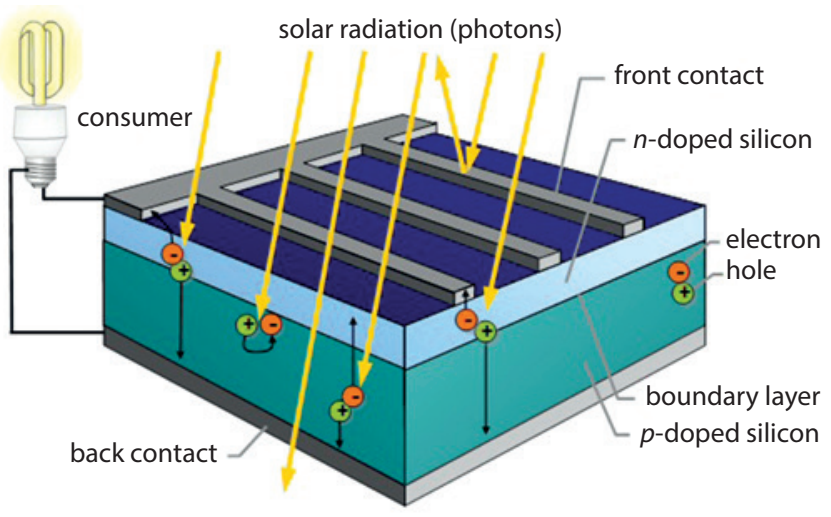

Fig. 1 Basic principle of a solar cell Source: Quasching, 2010
The PV module is a high resolution semiconducting photodiode. The module is made of silicon containing the $p-n$ transition. There are two suitable contacts on both sides on this $p-n$ transition. When sunlight falls on it, free electrons and holes are generated. The electric field of the $p-n$ transition separates them and sends them to the opposite sides - electrodes to the n-type layer, which becomes the negative pole of the PV cell, and the holes to the p-layer, which forms the positive pole. This process results in generating of electrical voltage on the contacts and direct current flowing through the connected load (Boleman and Fiala, 2009).

Reflected solar radiation that falls to the PV module is radiation that is reflected from the surfaces in front of the PV module. This reflection can provide a significant boost in power, such as on a bright day with snow. The amount of reflected radiation can be modelled as a product of total horizontal radiation (direct radiation of $I_{B H}$, plus $I_{D H}$ diffuse radiation) and landscape reflectance $k_{o}$. The fracture of this reflected energy, which will be captured by the PV module, depends on the inclination of the PV module, which results in the formulation of Eq. (1) for the reflected radiation falling on the inclined $I_{R C}$ PV module (Pandey and Katiyar, 2013):

$$
I_{R C}=k_{o}\left(I_{B H}+I_{D H}\right) \frac{1-\cos \sum}{2}, \| w 6 / m^{-2}
$$

Albedo expresses the ratio of the amount of reflected radiation and the amount of radiation incident to a particular surface. As a number without a physical dimension, the value of which lies in absolute values, it ranges from 0 to 1 , or, in percentage, it ranges from 0 to $100 \%$ (Chenni et al., 2011). 
It is known that the power of the PV panel decreases with partial shading. This paper deals with this very issue (Karatepe et al., 2007) and investigates several models of partial shading (Wang and Sheu, 2015).

\section{Material and methods}

To measure the dependence of PV module's power on shielding and reflected radiation, the measuring instrument consisted of Suntech STP 045S-12/Rb (monocrystalline PV module with an efficiency of 12.6 with dimensions $537 \times$ 665 mm (Suntech Power Holdings Co., Ltd., China), a 500 W halogen lamp with a J500-118 light bulb (Donghai Yifeng Lighting Co., Ltd., China), Metex ME-31 (Metex, USA) which was used both as a voltmeter and amperemeter. A solar meter KIMO SL 100 (Kimo Instruments, France) was used for detection of solar irradiation, and shutter for elimination of direct radiation. The measured samples were selected according to surface (the dimensions 1,250 $\times 600 \mathrm{~mm}$ ) which is usually used in practice; namely, these surfaces were tested: the anthracite colour roofing of the Mediteran, the Baumit white top facade plaster, the Baumit facade plaster, asphalt rubber SA 12, IPA V60 S35, stone with the fraction of $6-8 \mathrm{~mm}$, and Baumit concrete B20. Measurements were performed at the Physical Laboratory of AgroBioTech Research Centre. Three different series of measurements were performed on the surface samples. Each measurement from three series was repeated 10 times, and basic statistical characteristics (arithmetic average, standard deviation and variation coefficient) were calculated for every series of measurement. Experimental results were mathematically processed, arithmetic average was calculated for each measured operating parameter (the voltage and the current quantities) and these parameters were evaluated taking the probable relative deviation into account.
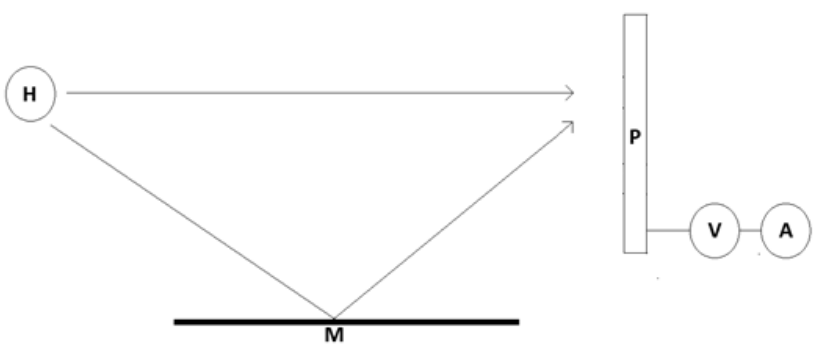

Fig. 2 Measurement scheme no. 1

$\mathrm{H}$ - halogen lamp, $\mathrm{M}$ - measured surface, $\mathrm{P}-\mathrm{PV}$ module, $\mathrm{V}$ - voltmeter, A - amperemeter

In measurement no. 1, PV module power in direct and reflected radiation was measured by the amperemeter and voltmeter. Eq. (2) was used to calculate the PV module power

$$
P_{D R}=U_{D R} \cdot I_{D R}
$$

where:

$P_{D R} \quad$ - power of the PV module in direct and reflected radiation; $\mathrm{W}$

$U_{D R} \quad$ - voltage in direct and reflected radiation; $\mathrm{V}$

$I_{D R} \quad$ - current in direct and reflected radiation; A

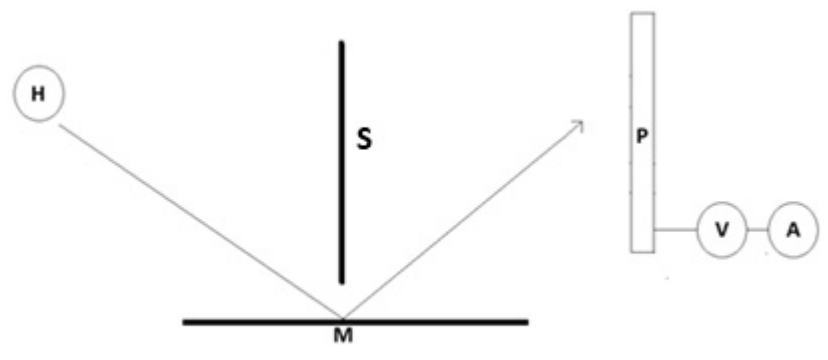

Fig. 3 Measurement scheme no. 2

$\mathrm{H}$ - halogen lamp, $\mathrm{M}$ - measured surface, $\mathrm{S}$ - shutter, $\mathrm{P}-\mathrm{PV}$ module, $\mathrm{V}$ - voltmeter, $\mathrm{A}$ - amperemeter

The specially designed shutter was used to eliminate direct radiation during the second series of measurements. The PV module power was determined experimentally only when the reflected radiation was detected. The power of the PV module was calculated by Eq. (3):

$$
P_{R}=U_{R} \cdot I_{R}
$$

where:

$P_{R} \quad$ - power of the PV module in reflected radiation; $\mathrm{W}$

$U_{R} \quad$ - voltage in radiation; $V$

$I_{R} \quad$ - current in reflected radiation; $\mathrm{A}$

The measured values of $P_{D R}$ and $P_{R}$ were compared and their differences in percentage were expressed.

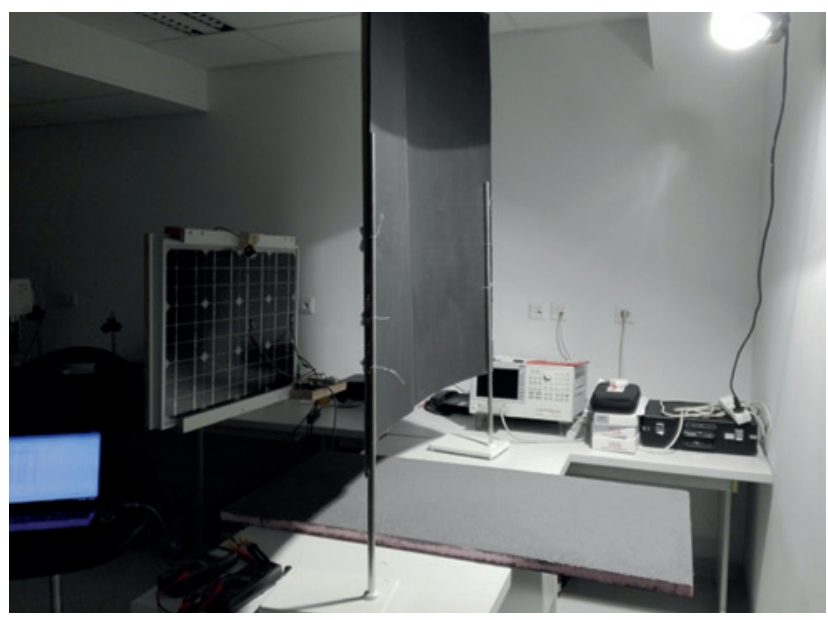

Fig. 4 Measurement of PV module power with shutter measurement no. 2

The partial shielding of the PV module was simulated in measurement no. 3. The PV module, which was used for detection of PV power, consists of 12 cells. At first, voltage and current were measured in the unshaded module. Then, voltage and current were measured in the module with one PV cell always covered. From the measured values, the PV module power was calculated according to Eq. (4):

$$
P=U \cdot I
$$

where:

$P \quad$ - power of the PV module; $\mathrm{W}$

U - voltage; $V$

I $\quad$ - current; A 


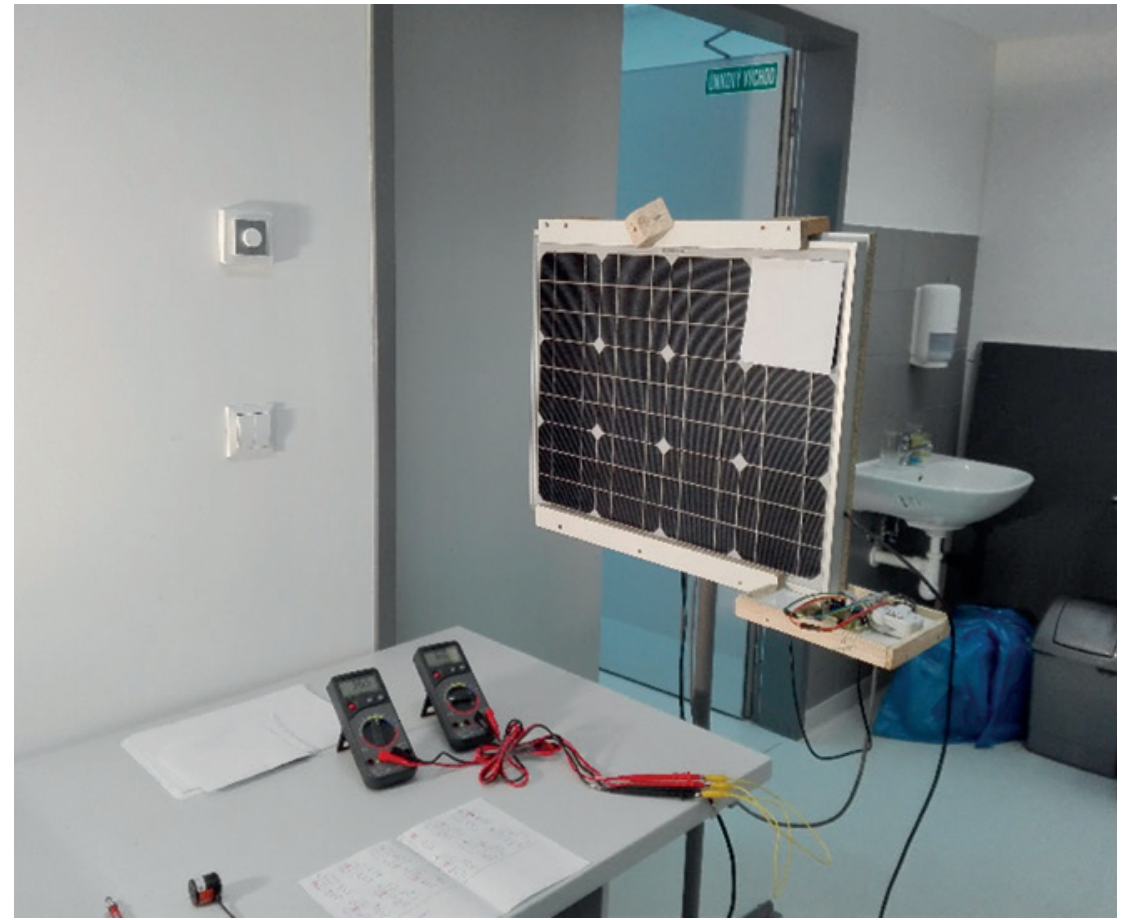

Fig. 5 Measurement of PV module power with partial shading - measurement no. 3

Table 1 Measured values $P_{D R}$ and $P_{R}$

\begin{tabular}{|l|c|c|c|}
\hline Material & $\boldsymbol{P}_{D R}$ in $\mathbf{W}$ & $\boldsymbol{P}_{\boldsymbol{R}}$ in $\mathbf{W}$ & $\boldsymbol{P}_{\boldsymbol{R}}$ in $\%$ \\
\hline \hline Concrete B20 & 5.52 & 0.081 & 1.47 \\
\hline White facade & 6.88 & 0.167 & 2.43 \\
\hline IPA V60 S35 & 4.87 & 0.046 & 0.94 \\
\hline Stone & 5.07 & 0.063 & 1.24 \\
\hline Asphalt rubber SA 12 & 4.88 & 0.045 & 0.92 \\
\hline Anthracite colour facade & 5.46 & 0.071 & 1.30 \\
\hline Roofing & 4.93 & 0.036 & 0.73 \\
\hline Arithmetic average & & & $\mathbf{1 . 2 9}$ \\
\hline
\end{tabular}

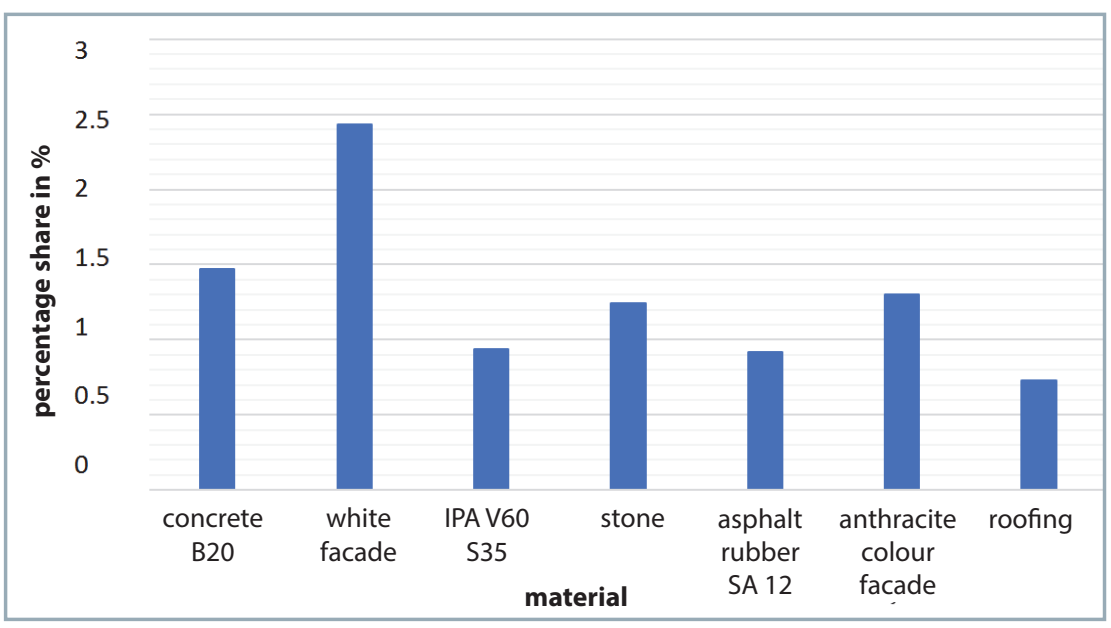

Fig. 6 The ratio of received reflected radiation to PV panel power output

\section{Results and discussion}

Table 1 shows the percentage of reflected radiation in the power of the PV module. With the average at $1.29 \%$, reflected radiation is considered not having any major impact on the PV module power.

Fig. 6 presents the percentage of reflected radiation in the $\mathrm{PV}$ module power; this figure shows that the pale surface reflects more radiation and has a higher albedo value. For each series of measurements, the average relative measurement deviation for current and voltage was calculated - the average of all measurements is $0.23 \%$.

From the measured values of the second part, a graph (Fig. 7) was constructed. This graph shows the PV module power at full power and the individual cells covered. It shows that the covering of any cell has a rapid impact on the power of the entire module. The arithmetic mean was calculated for the power of each covered cell and it was compared to full module power. It was found that the drop in one cell is up to $86.15 \%$.

This phenomenon is due to the fact that PV cells are connected in series - thus each cell should transfer the same current. If the cell is shaded, it stops producing current, but it becomes an electric current appliance. Unshaded cells sweep through the shielded cell stream, resulting in great power loss throughout the wiring. At the same time, the PV cell overheats and this might result in the damage of the PV module (Hot-Spots) or complete destruction. This problem can be avoided by connecting a semiconductor bridge diode, bypass diodes into a chain of PV cells. The bypass diode is connected in parallel to the cells in case of serial connection of the cells (Fig. 8). When the cell is shaded, the bypass diode transfers the current so that it runs around this cell and thus this solution prevents a rapid drop in power and possible damage to the PV module. At normal light time, the bypass diode has no function or no negative influence (Díaz-Dorado et al., 2017). 


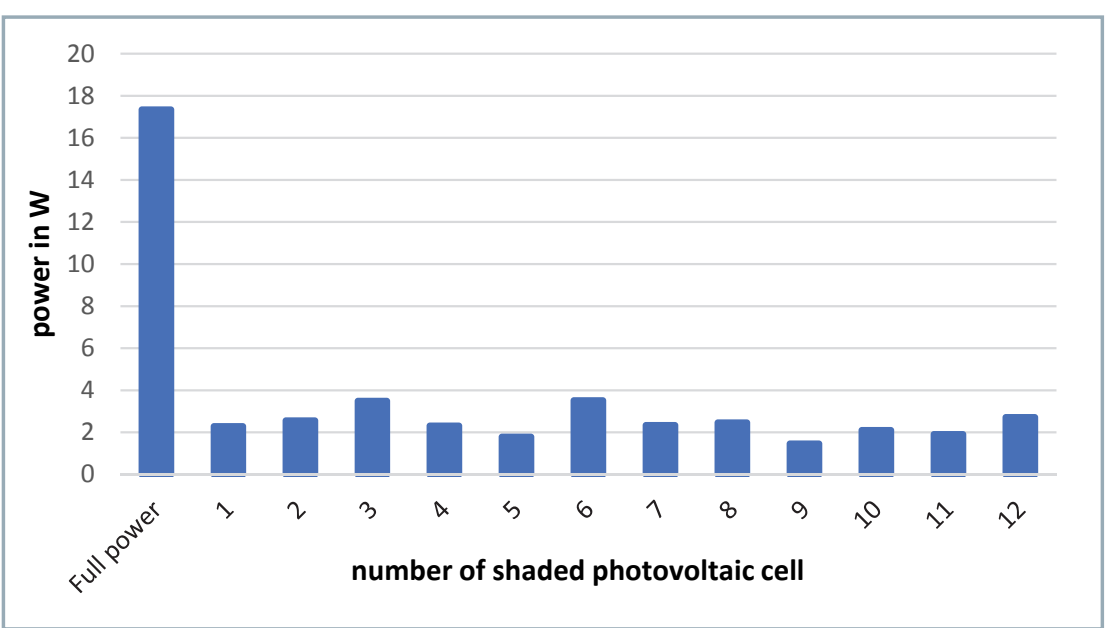

Fig. 7 PV panel output power with individual shading - measurement no. 3

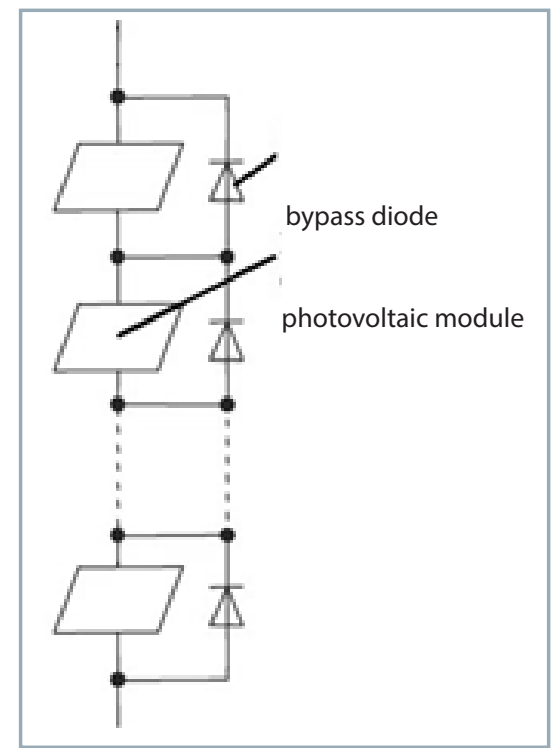
Fig. 8 Bypass diode connection

Source: Díaz-Dorado et al., 2017

\section{Conclusion}

The experimental research described in this paper was focused on detection of electrical parameters. The main aim was to determine the effect of reflected radiation and partial shading on the PV module power. The measurement results are presented in Figs 6 and 7 the ratio of received reflected radiation to PV panel power output and PV panel output power under individual cells shading condition are shown. It was found that the impact of reflected light on the PV module power was $1.29 \%$. The results further show that if we want to contribute to the power of the PV system, light objects should be placed around it because they have a higher albedo. By simulating the partial shading of the PV module, it has been found that the shading of any cell has a significant impact on the entire module power. The measurements showed a drop in power by $86.15 \%$. For this reason, PV systems should not contain objects (trees, buildings, etc.) that could shade PV cells during the day. If there are objects in the existing PV system that could cause shading, it is appropriate to install so-called bypass diodes. By using bypass diodes, it is possible to prevent the decrease in PV module power and eventual damage due to shielding.

\section{Acknowledgment}

The work was supported by the project KEGA 017SPU-4/2017 Multimedia Textbook of Physics for Engineers and the AgroBioTech project.

\section{References}

BOLEMAN, T. - FIALA, J. 2009. Renewable Energy Sources. Trnava : Tlačové štúdio Váry, 72 pp. ISBN 978-80-89422-07-4 (In Slovak: Obnoviteline zdroje energie).

DÍAZ-DORADO, E. - CIDRÁS, J. - CARRILLO, C. 2017. Discretized model for partially shaded PV arrays composed of PV panels with overlapping bypass diodes. In Solar Energy, vol. 157, no. 3, pp. 103-115.

CHENNI, R. - MATAGANE, E. - KHENNANE, M. 2011. Study of solar radiation in view of photovoltaic systems optimization. In Smart Grid and Renewable Energy, vol. 2, no. 4, pp. 367-374.

KARATEPE, E. - BOZTEPE, M. - ÇOLAK, M. 2007. Development of a suitable model for characterizing photovoltaic arrays with shaded solar cells. In Solar Energy, vol. 81, no. 8, pp. 977-992.
LIBRA, M. - BERÁNEK, V. - SEDLÁČEK, J. POULEK, V. - TYUKHOW, I. I. 2016. Roof photovoltaic power plant operation during the solar eclipse. In Solar Energy, vol. 140, no. 4, pp. 109-112.

LIBRA, M. - POULEK, V. - KOUŘíM, P. 2017. Temperature changes of I-V characteristics on photovoltaic cells as consequence of the Fermi energy level shift. In Research in Agricultural Engineering, vol. 63, no. 1, pp. 10-15.

McEVOY, A. - MARKVART, T. - CASTANER, L. 2011. Practical Handbook of Photovoltaics. Amsterdam : Academic Press, 1268 pp. ISBN 9780123859341.

OLŠAN, T. - LIBRA, M. - POULEK, V. CHALUPA, B. - SEDLÁČEK, J. 2016. Combination of three methods of photovoltaic panels damage evaluation. In Scientia Agriculturae Bohemica, vol. 48, no. 2, pp. 98-101.

PANDEY, C. K. - KATIYAR, A. K. 2013. Solar Radiation: Models and Measurement Techniques. In Journal of Energy, vol. 2013, no. 3, pp. 1-8.

POULEK, V. - KHUDYSH, A. - LIBRA, M. 2016. Self powered solar tracker for Low Concentration (LCPV) systems. In Solar Energy, vol. 127, no. 1, pp. 109-112.

QUASCHING, V.2010. Renewable Energy and Climate Change. Chichester : John Wiley \& Sons Ltd, 344 pp. ISBN 978-0-470-74707-0. WANG, Y. J. - SHEU, R. L, 2015. Probabilistic modelling of partial shading of photovoltaic arrays. In Internation Journal of Photoenergy, vol. 2015, no. 1, pp. 1-10. 